\title{
International Support For U.S. Foreign Policy: The Role Of Foreign Aid, Trade Integration And Social Development
}

Edwin A. Sexton, (E-mail: sextonea@vmi.edu), Virginia Military Institute Atin Basu, (E-mail: basua@vmi.edu), Virginia Military Institute Tinni Sen, (E-mail: sensb@vmi.edu), Virginia Military Institute

\begin{abstract}
We examine the factors that determine how often other countries vote with the U.S. in the U.N. General Assembly as a measure of their support for U.S. interests. We find that U.S. aid does not particularly induce other countries to vote with it on issues that are important to the U.S. However, countries with a higher level of social development, as measured by the HDI, seem to vote more often with the U.S. in the U.N. Moreover, it also seems that trading with the U.S. aligns other countries with the U.S to some degree.
\end{abstract}

\section{Introduction}

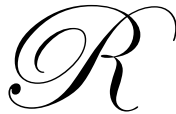

ecently, in his National Security Strategy (2002), President Bush linked foreign aid to U.S. foreign policy, specifically to national security. This suggests a redirection of the role of foreign aid from protecting allies against communism to promoting elements of social development. In this new strategy, the role of foreign aid is to promote democracy and economic growth, improve health and education, reduce conflict and provide humanitarian aid - all in the national interest ${ }^{1}$. Another view of the role of foreign aid is that it directly influences recipient governments in matters of U.S. foreign policy. In this capacity, foreign aid is viewed as a payment for choosing a policy in the U.S. interest. However, it is still unclear whether foreign aid really promoted the national interest during and after the cold war (see, for example, Sexton and Decker, 1992, and Wang, 1999 , for conflicting positions). The pertinent question then becomes whether foreign aid has successfully promoted the national interest in the post $9 / 11$ era.

There is evidence to suggest that in the post cold war era, ideological goals have become more important for U.S. foreign policy than systemic security goals (Meernik, Krueger, and Poe, 1998). Some of this change is driven by the demise of the threat from communism. This may also be a response to an uncertain world order. For example, a large literature suggests that democratic dyads have less conflict (Bueno de Mesquita and Lalman 1992; Dixon 1994; Lake 1992; Maoz and Russett 1993). In this world-view, it may be possible to use foreign aid as an "external inducement" to promote democracy and stability (Ikenberry and Kupchan, 1990). If such inducements are indeed successful in promoting American ideological goals abroad, one might plausibly hypothesize that foreign aid is correlated with an alignment of interests between the U.S. and recipient states. In fact, U.S. aid could be instrumental in causing this convergence.

In this paper, we attempt to provide a preliminary evaluation of whether, in the post Cold War international order, U.S. aid has led to an alignment of interests between the U.S. and recipient states. It might be too early to see if this re-emphasis on tying U.S. aid to national security and foreign policy has succeeded in influencing the

\footnotetext{
${ }^{1}$ Foreign Aid In The National Interest - Promoting Freedom, Security, and Opportunity.
} 
behavior of other countries. However, it may be interesting to get a sense of how things are now, if only as a baseline for future evaluation of current aid policy.

We also study other factors that may help in promoting the U.S. interest as well. Specifically, we look at trade and the level of social development of a country.

Countries may particularly value their trading relationship with a dominant economy like the U.S. Therefore, other things being equal, countries whose fortunes are tied to trading with the U.S. should find it in their self-interest to be more supportive of U.S. interests. This position seems to be consistent with the public choice perspective that suggests that individuals, and not countries, trade (Rowley in Shughart and Razzolini ed., 2001). Thus, those elites who benefit from trade with the U.S. will very likely encourage their governments to promote those international positions that are favored by the U.S. (see, for example, Ikenberry and Kupchan, 1990). Additionally, some academics (e.g. Alfred E. Eckes in Foreign Affairs, 1992) argue that since the days of Truman, trade has been used as a tool for promoting U.S. interests abroad. In either case, it is plausible to expect that the volume of trade generated between the U.S. and a trading partner is linked to an alignment of interests between the two.

The Bush administration's National Security Strategy clearly recognizes that global social development is in the American interest. ${ }^{2}$ The focus of American aid has shifted from encouraging economic growth to increased social development in areas such as health and education. Thus it would be interesting to see if countries with greater levels of social development indeed align their interests with those of the U.S.

With this in mind, we ask three questions:

(1) Does U.S. foreign aid align the interests of recipient countries to that of the U.S.?

(2) Do higher trade volumes align the interests of the U.S.'s trading partners with U.S. interests?

(3) Do countries with higher levels of social development have interests similar to that of the U.S?

In this study, we use voting patterns at the United Nations (U.N.) as a measure of a nation's alignment with U.S. interests. The percentage of times a country votes with the U.S. on important issues is our measure of the degree to which that country's foreign policy is aligned with that of the U.S.

Keohane (1966) and Black (1968) were the first to theorize a direct connection between U.S. foreign aid and U.N. voting patterns. This link has become the working hypothesis in several empirical works. The results, however, are inconclusive. Several studies conclude that U.S. aid has been used effectively to induce countries to vote in favor of U.S. policies (Bernstein and Alpert, 1971, Rai, 1972, 1980, Wittkopf, 1973 and Wang, 1999). On the other hand, several other studies could not find any direct linkage between aid and voting patterns (Kato, 1969, Kegley and Hook, 1991 and Sexton and Decker, 1992).

In our study, we focus on the votes on issues that are important to the U.S ${ }^{3}$. Previous studies used the voting records of all U.N. resolutions. Bernstein and Alpert (1991) and Wang (1999 are exceptions to this. We agree with Wang that it is unlikely that U.S. aid is used to influence each and every issue. It is more likely that this influence is exerted on issues that are crucial to U.S. national interests. Moreover, we understand that the U.S. may not always find the U.N. itself relevant to its' interest. Thus we may not be losing much information by focusing only on important votes.

\section{Empirical Analysis}

\subsection{Data}

Our data set consists of information on the 162 countries that voted in the $57^{\text {th }}$ General Assembly for which we have complete information.

\footnotetext{
${ }^{2}$ See Chapter VII of "The National Security Strategy of the United States of America" at the White House website.

${ }^{3}$ Whether a vote is important or not is determined by the U.S. State Department.
} 
The data are drawn from the year 2002. The cross-sectional nature of this methodology is limiting. Obviously, an existing trend is better captured in a time-series analysis ${ }^{4}$. However, since the current administration was elected in 2000, the appropriate baseline for its policies is the 2001-2002 period. Also some of the data is reported with five-year intervals making trend analysis difficult.

The U.S. State Department reports the voting records of the members of the U.N. General Assembly. It also records the corresponding levels of U.S. assistance to these countries. This data set yields two of our variables.

The first is the percentage of votes important to the U.S. in which the country and the U.S. took the same position in 2002 (Impvotes). These important votes are summarized in Table I below.

Table 1

Brief description of votes considered important to the U.S. by the U.S. State Department

\begin{tabular}{|l|c|}
\hline Resolution Description and date & Resolution number \\
\hline IAEA Report, November 11 & $\mathrm{A} / \mathrm{Res} / 57 / 9$ \\
\hline U.S. Embargo against Cuba, November 12 & $\mathrm{A} / \mathrm{Res} / 57 / 11$ \\
\hline National legislation on transfer of arms, November 11 & $\mathrm{A} / \mathrm{Res} / 57 / 66$ \\
\hline Total elimination of nuclear weapons, November 22 & $\mathrm{A} / \mathrm{Res} / 57 / 78$ \\
\hline Risk of nuclear proliferation in the Middle-East, November 22 & $\mathrm{A} / \mathrm{Res} / 57 / 97$ \\
\hline $\begin{array}{l}\text { Work of the special committee investigating Israeli treatment of Palestinians and other } \\
\text { Arabs in the Occupied Territories, November 22 }\end{array}$ & $\mathrm{A} / \mathrm{Res} / 57 / 124$ \\
\hline Future operations of INSTRAW, December 18 & $\mathrm{A} / \mathrm{Res} / 57 / 175$ \\
\hline $\begin{array}{l}\text { Rights of the child, December 18 } \\
\text { The fight against racism, racial discrimination, xenophobia, and related intolerance and } \\
\text { follow up on implementing the Durban declaration, December 18 }\end{array}$ & $\mathrm{A} / \mathrm{Res} / 57 / 190$ \\
\hline Optional protocol to the convention against torture, December 18 & \\
\hline Globalization and human rights, December 18 & $\mathrm{A} / \mathrm{Res} / 57 / 199$ \\
\hline Human rights in Sudan, December 18 & $\mathrm{A} / \mathrm{Res} / 57 / 205$ \\
\hline Situation of Human rights in Iraq, December 18 & $\mathrm{A} / \mathrm{Res} / 57 / 230$ \\
\hline Effects of the use of depleted uranium, October 25 & $\mathrm{A} / \mathrm{Res} / 57 / 232$ \\
\hline & $\mathrm{A} / \mathrm{Res} / 57 / 233$ \\
\hline
\end{tabular}

The second is the level of U.S. aid provided to these countries in the year 2001 (in thousands of U.S. dollars). We used data on U.S. aid in 2001, not 2002, because the effect of assistance on voting patterns is likely to show up with a lag. U.S. aid numbers are the State Department's estimates of aid from the Foreign Operations, Export Financing, and Related programs Act and P.L. 480 funds.

We obtain data on total aid to this group of countries from the World Development Indicators' (WDI) database of the World Bank. This data includes the transfer of goods and services by donor, including loans with a grant element of $25 \%$, and the value to the donor of technical assistance and cooperation less repayments of loan principle. We then combined the aid data to calculate U.S. aid as a percentage of total aid to each of the countries in our data set (USAid). Note that there are a number of donor countries other than the U.S. If aid recipient countries feel that U.S. aid is a small proportion of the total aid they receive, they are less likely to feel obligated to U.S. interests in the U.N. Thus, U.S. aid as a proportion of total aid received is more likely to drive recipient countries to act in the U.S. interest than the actual amount of U.S. aid.

The United Nations Development Programme's (U.N.D.P.) constructs a Human Development Index (HDI) to measure how developed a nation is. The HDI is a composite index of three equally weight component indices.

\footnotetext{
${ }^{4}$ Previous studies that are similarly constrained are Wittkopf (1973) and Sexton and Decker (1992) (compare patterns across two years,) and Kegley and Hook (1991) (compare patterns across 8 years). The exception to this is Wang, 1999
} 
The first index is a purchasing power parity index of per capita national income, the second is a life expectancy index, and the third is an education index that measures both gross enrollment and adult literacy. We use the HDI as a measure of the degree of social development in a country. A higher index number denotes a higher degree of social development. The HDI is reported once every five years. We use the most recent HDI data for the year 2000.

Data on the amount of trade with the U.S. is obtained from the 2002 press release of the U.S. Census Bureau's Foreign Trade Statistics division. This data set yields both imports to the U.S. and exports from the U.S. The sum of imports and exports (Trade) is used as a measure of the nation's total trade integration with the U.S., measured in millions of U.S. dollars.

We also developed a series of dummy variables based on the various global political alignments. Accordingly, we had dummy for a member of the Arab block of nations (Arab), for whether the country currently follows a communist political philosophy (Communist), whether the country is a former member of the Soviet block of nations (Ex-Soviet), and whether the country is a non-aligned nation (Non-Aligned). ${ }^{5}$ The group of countries that were western European, or were closely aligned with western European nations, formed the base for our dummy variables. We developed these variables in order to capture both traditional and emerging political alliances. We hypothesize that this could also be a proxy for how philosophically close a country is to the U.S.'s position.

\section{Summary Statistics}

Before proceeding to our econometric analysis, we take a look at the voting records of the 160 nations in our data set. Relevant statistics are reported in Tables 2 and 3.

Table 2

Summary Statistics for Key Variables

\begin{tabular}{|l|c|c|c|}
\hline Variable & Mean & Minimum & Maximum \\
\hline U.N. 2002 Important Votes & $30 \%$ & 0 & $84.6 \%$ \\
\hline Arab Nations & 11.0 & 0 & 1 \\
\hline Non-Aligned Nations & 60.0 & 0 & 1 \\
\hline Western Nations & 13.0 & 0 & 1 \\
\hline Former Soviet or Communist Nations & 16.0 & 0 & 1 \\
\hline U.S. Aid 2001 & $\$ 53,503,270$ & 0 & $\$ 2,813,796,00$ \\
\hline Trade & $\$ 1,082,506,000$ & $1,600,000$ & $\$ 370,010,700,000$ \\
\hline HDI & .60 & .275 & .942 \\
\hline
\end{tabular}

First, we determine from Table 2 that approximately $11 \%$ of the countries are in the Arab subgroup, with $13 \%$ from the Western subgroup and 16\% from the Communist and Ex-Soviet subgroups. The remaining countries are Non-aligned.

Norway has the highest HDI, at .942 and Sierra Leone has the lowest at .275 - the average being .60. The average amount of imports and exports combined is over one billion dollars with Canada having by far the largest amount of trade with the U.S. and Bhutan having the lowest combined amount of trade with $\$ 800,000$ in exports and $\$ 800,000$ in imports with the U.S.

\footnotetext{
${ }^{5}$ These classifications follows the U.S. State Department's own classification.
} 
Table 3

Grouped Summary of Data for Voting Percentages and Aid

\begin{tabular}{|l|c|c|}
\hline Proportion of Votes With the U.S. & Number of Countries & Percent Receiving U.S. Aid \\
\hline $50.1-100 \%$ & 33 & $45 \%$ \\
\hline $0-50 \%$ & 129 & $85 \%$ \\
\hline & & \\
\hline $80.1-100 \%$ & 1 & $100 \%$ \\
\hline $60.1-80 \%$ & 2 & 0 \\
\hline $40.1-60 \%$ & 44 & $61 \%$ \\
\hline $20.1-40 \%$ & 42 & $81 \%$ \\
\hline $0-20 \%$ & 73 & $86 \%$ \\
\hline
\end{tabular}

The first noteworthy trend captured by the summary statistics in Table 3 is how seldom other nations vote with the U.S. in the U.N. Of the issues that are deemed important to the U.S., only 3 out of the 162 countries $(1.85 \%)$ voted with the U.S. more than $60 \%$ of the time, and only 33 countries (20\%) voted with the U.S. more than $50 \%$ of the time.

Also in Table 2, we note that Israel received about 3 billion dollars in aid. This is by far the largest amount of aid received by any country. Israel was also the country that voted with the U.S. the highest percent of times. However, the country that received the next largest amount of aid, Egypt, voted with the U.S. only 20\% of the time.

Perhaps the most interesting information comes from a look at the voting patterns of the nations who receive U.S. aid. With the exception of Israel, the highest percent of countries that received aid were those that voted with the U.S. the least. For example, of those countries that voted with the U.S. 0 to $20 \%$ of the time, $86 \%$ received U.S. aid. One could speculate that the U.S. gives aid to countries that seldom vote with U.S. interests in an effort to win them over to our point of view. However, since Sexton and Decker (1992) found this same pattern in data from the late 1980's, it would appear that the intervening years of aid have not produced the desired effect.

Further analysis of the voting patterns within the various groups of nations is also revealing. Of the 18 Arab block nations, none voted with the U.S. more than 50\% of the time on important votes, and 14 out of the 18 (78\%) voted with the U.S. less than $20 \%$ of the time. Yet, $78 \%$ of those nations received U.S. aid in the year prior to the votes being taken.

All of the 21 countries in the Ex-Soviet group received aid. Forty three percent of these nations voted with the U.S. less than $40 \%$ of the time. The two countries in our data set that are still communist are Cuba and China. They both received aid, and voted with the U.S. less than $20 \%$ of the time.

Only $23 \%$ of the 26 Western countries received aid from the U.S. All of them voted with the U.S. at least $50 \%$ of the time on the important votes and $88 \%$ of them voted with us more than $60 \%$ of the time on these votes. Of the 107 Non-aligned countries, $87 \%$ received assistance, yet only $12 \%$ of them voted with the U.S. more than $50 \%$ of the time on important votes. Only $6 \%$ voted with the U.S. more than $50 \%$ of the time on all votes that were cast.

\section{Model and Results}

With this information as background, we hypothesize the following:

a. The U.S. is able to use foreign aid to induce countries to favor its foreign policy.

$b$. The more integrated a country is with the U.S. economy, the more likely it is to favor U.S. foreign policy.

c. The more socially developed a country is, the more likely it is to favor U.S. foreign policy. 

variable:

To test these hypotheses, we performed OLS regressions using important votes (Impvotes) as the dependant

Impvotes $=\beta_{0}+\beta_{1}$ USAid $+\beta_{2}$ Arab $+\beta_{3}$ ExSoviet $+\beta_{4}$ Nonaligned $+\beta_{5}$ Communist $+\beta 6$ Trade $+\beta_{7} H D I+\varepsilon_{i}$

The results of the regression are reported in Table 4, below.

Table 4

Effects of Aid, Trade and HDI on U.N. Voting Patterns

\begin{tabular}{|c|c|c|}
\hline \multicolumn{3}{|c|}{ Dependent Variable Important Votes 2002} \\
\hline $\begin{array}{l}\text { Independent } \\
\text { Variable }\end{array}$ & $\frac{\text { Model 1 }}{(\mathrm{n}=162)}$ & $\frac{\text { Model 2 }}{(\mathrm{n}=160)}$ \\
\hline Intercept & $\begin{array}{l}0.047 \\
(0.058)\end{array}$ & $\begin{array}{l}0.051 \\
(0.87)\end{array}$ \\
\hline $\begin{array}{l}\text { U.S. Aid } 2001 \\
\text { (As a percentage of total aid) }\end{array}$ & $\begin{array}{l}.00021^{*} \\
(6.88)\end{array}$ & $\begin{array}{l}.0000596 \\
(0.47)\end{array}$ \\
\hline Trade & $\begin{array}{l}.454^{*} \\
(3.628)\end{array}$ & $\begin{array}{l}.446^{*} \\
(3.62)\end{array}$ \\
\hline Arab & $\begin{array}{l}-0.146^{*} \\
(-3.84)\end{array}$ & $\begin{array}{l}-0.146^{*} \\
(-3.7)\end{array}$ \\
\hline Ex-Soviet & $\begin{array}{l}-0.019 \\
(-0.57)\end{array}$ & $\begin{array}{l}-0.019 \\
(-0.58)\end{array}$ \\
\hline Non-Aligned & $\begin{array}{l}-0.105^{*} \\
(-3.48)\end{array}$ & $\begin{array}{l}-0.11 * \\
(-3.56)\end{array}$ \\
\hline Communist & $\begin{array}{l}-0.241^{*} \\
(-12.15)\end{array}$ & $\begin{array}{l}-0.243^{*} \\
(-12.16)\end{array}$ \\
\hline HDI & $\begin{array}{l}0.467^{*} \\
(7.64)\end{array}$ & $\begin{array}{l}0.465^{*} \\
(7.6)\end{array}$ \\
\hline $\mathrm{R}^{2}$ & 0.54 & 0.51 \\
\hline $\mathrm{F}$ & $25.75^{*}$ & $22.39 *$ \\
\hline (Student's $t$ ratio is in parentl & cant at the & \\
\hline
\end{tabular}

Israel and Egypt receive much more aid than any other nation. Therefore, we ran the regressions with and without Israel and Egypt. In Table 4, when the sample size is 162, Israel and Egypt are included (Model 1), and when the sample size is 160, Egypt and Israel are not included (Model 2). 
First, we look at the impact of U.S. aid on important votes. Notice that in Model 2, when Israel and Egypt are excluded from the sample, the coefficient on USAid is not significantly different from zero. This indicates that the amount of aid that the U.S. gives to a country as a percentage of that country's total aid does not influence its decision to vote with the U.S. in the U.N. However, in Model 1, when we include those two countries, USAid is statistically significant. This is easily explained by the fact that the U.S. gives such large amounts of aid to Israel and Israel also votes with the U.S. such a large portion of the time.

Perhaps one reason for the lack of correlation between U.S. aid to a country and its' tendency to vote with the U.S. is that the U.S. gives too little aid. Apart from Israel and Egypt, the amount of aid to most countries is relatively small. We note that even though Egypt gets the second highest amount of aid (and much more than other countries receive from the U.S) it is still a third less than what Israel got in 2001. Egypt's voting record, however, puts it in the lowest quintile as far as voting with U.S. interests is concerned. Possibly, Israel votes with the U.S. enough times to overshadow Egypt's effect in the regression. Thus, it may not be just the size of the aid that matters. Anecdotal evidence suggests that Egypt's vote in the U.N. may be more a show of solidarity with other Arab states and domestic constituencies against American policy with regard to the Israel-Palestinian conflict. In other words, while both Israel and Egypt get very large amounts of aid compared to other countries, their voting record in the U.N. are very different. This suggests that U.S. aid probably does not have much of a real impact on recipient countries votes in the U.N.

Next, we look at the impact of trade on voting patterns. In both models, the coefficient on the Trade variable is positive and significant. This suggests that the more integrated a country is with the U.S. in terms of imports and exports the more likely it is to vote with the U.S. on important votes in the U.N., holding all else constant. This indicates that if a country either relies heavily on U.S. markets for its goods (has a large dollar value of imports to the U.S.) or has come to rely heavily on U.S. goods for its domestic consumer markets (has a large dollar value of exports from the U.S.) or both, it tends to be more supportive of U.S. positions in the U.N. The actual value of the coefficient on Trade is also larger by several orders of magnitude than the value on the coefficient on U.S. Aid. This would suggest that increasing trade integration with the U.S. is a more effective foreign policy strategy than increasing foreign aid.

Regardless of whether Israel and Egypt are in the sample, we note that countries in the Arab block, communist countries, and non-aligned countries all consistently vote less with the U.S. than traditionally western nations. For example, holding constant the level of U.S. aid, the level of trade, and the level of human development, Arab countries are significantly less likely to vote with the U.S. in the U.N. than western countries.

Interestingly, though, countries that used to be part of the Soviet bloc (either explicitly as a part of the Soviet Union or implicitly as a part of the Warsaw pact) tend to vote less with the U.S. than western countries, but not significantly so. This may suggest that these countries, as a bloc, do not have a pattern of voting with or against the U.S. This is plausible when we consider that these countries cover the political spectrum from a thriving democracy in the Czech Republic to the Stalinist dictatorship of Azerbaijan. Therefore, they may have as wide a variety of opinions about U.S. policy as the western bloc does.

Next we look at HDI, our proxy for social development. HDI has a positive and significant relationship with Impvotes in both models. This suggests that the more socially developed nations tend to vote with the U.S. in the U.N. It is interesting to note that the correlation between U.S. aid and HDI is essentially zero (the variance inflation factor is equal to 1.) Thus, another reason for the lack of a correlation between U.S. aid and Impvotes may be that U.S. aid has just not been appropriately targeted at promoting social development. It seems that the stated U.S. foreign aid policy has not yet taken effect. However, as would be expected, those countries that are more socially developed, as is the U.S., tend to hold views similar to the U.S. in the U.N.

\section{Conclusion}

The current administration appears to believe that the role of foreign aid is to promote democracy and social development, and that this is in the national interest. The presumption is that by fostering social development, 
foreign aid will create allies that will agree with the U.S.'s position in international issues. This would be true if countries that are more socially developed tend to agree with the U.S. on matters perceived as important by the U.S.

In this paper, we find evidence to support this hypothesis. Our results show that countries with a higher Human Development Index tend to favor the U.S. in issues that are important to the U.S interest. In other words, the more socially developed a country is, the more likely it is to favor U.S. foreign policy. Therefore, it may be possible to argue that foreign aid has a much better chance of being effective in the national interest if used to foster social development. Unfortunately, the lack of correlation between aid and a country's HDI does not evidence that the U.S. is currently using aid for this purpose.

We also find that trade fosters agreement between nations. Countries that have large volumes of trade with the U.S., either with imports or with exports, tend to support the U.S. on issues that it considers important. Therefore, we conclude that those countries that are more integrated with the U.S. via trade are more likely to favor the U.S. position in international issues.

Finally, we look to see if the traditional role of foreign aid is still relevant. Traditionally, one of the primary uses of foreign aid was as a means to induce nations to side with the U.S. against Soviet interests. We find that aid, absent that aid we give to Israel, generally has no impact on the voting patterns of nations. We also find that it has essentially no impact on a country's HDI.

With the demise of the Soviet Union and the emergence of new sources of threats to the U.S., President Bush's reevaluation of the use of foreign aid appears particularly timely. Because U.S. foreign aid has been found by many researchers over a long period of time to have little or no impact on U.N. voting patterns, it is possible to draw the conclusion that the U.S. does not care how nations vote in the U.N. In fact, the age of using of foreign aid to buy friends may give way, as the current administration suggests in their foreign policy statement, to a new era focusing on third world social development and trade integration.

We would like to acknowledge the work of Austin Cam and Lincoln Clark in helping us put the dataset together. We also benefited from comments made by Ronald Wintrobe and other participants at the Public Choice Society meetings in March 2003. Any remaining errors are our own.

\section{References}

1. Bernstein, S.J. and E.J. Alpert (1971) 'Foreign Aid and Voting Behavior in the U.N." The Admission of Communist China'. Orbis 15:963-977

2. Black, L. (1968) 'The Strategy of Foreign Aid'. Princeton, NJ: D. Van Nostrand.

3. Bueno de Mesquita, B., D. Lalman (1992) 'War and Reason'. New Haven: Yale University Press.

4. Central Intelligence Agency, 2000, 2001 World Factbook. http://www.cia.gov/cia/publications/pubs.html $(1 / 30 / 03)$

5. Christopher, W. (1995) 'The Foreign Affairs Budget: Our Foreign Policy Cannot Be Supported on the Cheap'. U.S. Department of State Dispatch 6:285-291.

6. Dixon, W.J. (1994) 'Democracy and the Peaceful Settlement of Conflict.' American Political Science Review 88:14-32.

7. Doherty. C. J. (1995) 'Foreign Aid: Republicans Poised to Slash International Programs.' Congressional Quarterly Weekly Report 53:1334-1336.

8. $\quad$ Doyle, M. (1986) 'Liberalism and World Politics'. American Political Science Review 80: 1151-1169.

9. $\quad$ Easerly, W. (2001) The Elusive Quest For Growth. Cambridge, MA: MIT Press.

10. Eckes, A.E. (1992). 'Trading American Interests.' Foreign Affairs 71:135-154.

11. Gastil, R. (1989) Freedom In the World: Political Rights and Civil Liberties. Westport, CT: Greenwood Press.

12. Ikenberry, G. and C.A. Kupchan (1990). 'Socialization and Hegemonic Power.' International Organization. 44:283-315. 
13. Kato, M. (1969) 'A Model of U.S. Foreign Aid: An Application of a Decision Making Scheme'. In Approaches to Measurement in International Relations, edited by J. Miller, 198-215. New York: Appleton-Century-Crofts

14. Kegley, C., and S. Hook (1991) 'U.S. Foreign Aid and U.N. Voting: Did Reagan's Linkage Strategy Buy Deference or Defiance?' International Studies Quarterly 35: 295-312.

15. Keohane, R.O. (1966) 'Political Influence in the General Assembly'. International Conciliation no. 557:164.

16. Lake, D.A. (1992) 'Powerful Pacifists: Democratic States and War.' American Political Science Review. 86:24-37.

17. Maoz, z. and B. Russett (1993) 'Normative and Structural Causes of Democratic Peace, 1946-1986.' American Political Science Review. 87:624-38.

18. McNeill, D. (1981) The Contradictions of Foreign Aid, London: Croom Helm.

19. Meernik, J., E.L. Krueger, S.C. Poe. (1998) 'Testing Models of U.S. Foreign Policy: Foreign Aid During and After the Cold War.' The Journal of Politics. 60:1.

20. Perkins, D.H., S. Radelet, D.R. Snodgrass, M. Gillis, and M. Roemer (2001) Economics of Development. 5 Ed. New York, NY: W.W. Norton.

21. Rai, K. (1980) 'Foreign Aid and Voting in the U.N. General Assembly'. Journal of Peace Research 17:269-277.

22. Rai, K. (1972) 'Foreign Policy and Voting in the U.N. General Assembly'. International Organization 26:589-594.

23. Rowley, C.K. (2001) 'The International Economy in Public Choice Perspective.' The Elgar Companion To Public Choice - editors William F. Shughart II and Laura Razzolini. Cheltenham U.K.: Edward Elgar.

24. Sexton, E.A., and T.N. Decker (1992) U.S. Foreign Aid: Is It For Friends, Development or Politics? Journal of Social Political and Economic Studies 17: 303-315.

25. U.S. Agency for International Development (2002) 'Foreign Aid in the National Interest: Promoting Freedom, Security, and Opportunity'.

26. U.S. Department of State 2000, 2001 Voting Practices in the United Nations. http://state.gov/p/io/conrpt/vtgprac/ (1/30/03)

27. Wang, T.Y., (1999) U.S. Foreign Aid and U.N. Voting: An Analysis of Important Issues. International Studies Quarterly 43: 199-210.

28. White House (2002) The National Security Strategy of the United States of America, http://www.whitehouse.gov/nsc/nss.html/ (10/28/03)

29. Wittkopf, E. (1973) 'Foreign Aid and the United Nations Votes'. American Political Science Review 67:868-888.

30. World Bank, 2000, 2001 World Development Indicators. $\quad$ http://publications.worldbank.org/WDI/ $(1 / 30 / 03)$ 
Notes 